\title{
Responses in the James River Arm of Table Rock Lake, Missouri (USA) to point-source phosphorus reduction
}

\author{
Daniel Obrecht, Anthony P. Thorpe and John R. Jones
}

\section{Introduction}

Missouri reservoirs span a broad range of trophic states, with cross-system variation being determined largely by nonpoint source inputs from cropland (JONES \& KNOWLTON 1993, JONES et al. 2004). About $10 \%$ of the state's major reservoirs receive pointsource inputs from municipalities, and eutrophication responses to these nutrient loads have been described in a few cases (KNOWLTON \& JONES 1989, KNOWLTON \& JONES 1990). Table Rock Lake, a U. S. Army Corps of Engineers impoundment on the White River in southern Missouri $\left(170 \mathrm{~km}^{2}\right.$; Fig. 1), shows spatial variation in nutrient concentrations and

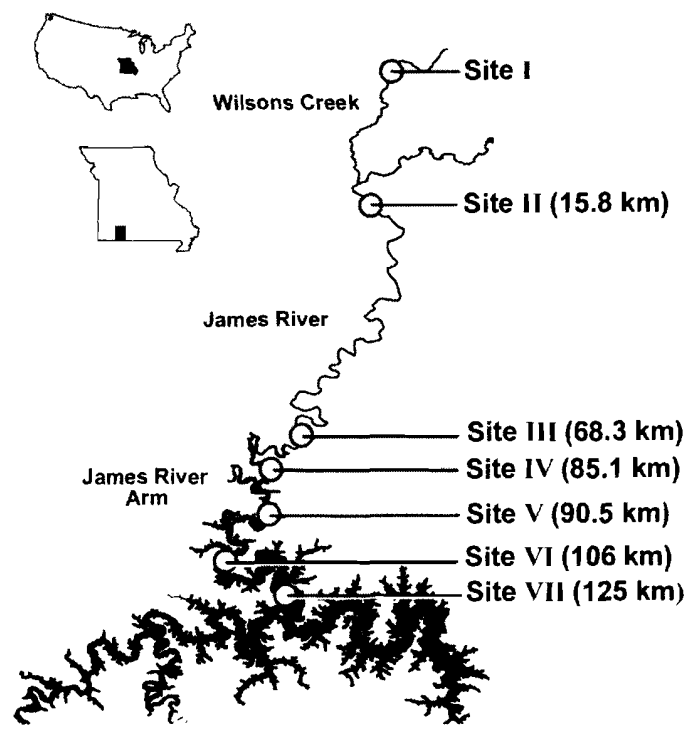

Fig. 1. Map showing seven sample sites within the James River Basin of Table Rock Lake, Missouri (USA). Site I is located directly below the City of Springfield's Southwest Treatment Plant (STP). The distance from STP is listed in parenthesis for the other sites. algal biomass that closely matches the magnitude of cross-system variation within the entire state (KNOWLTON \& JONES 1989). As a consequence of point-source input from the Springfield Southwest Treatment Plant (STP), the upper James River Arm has historically been the most enriched region of Table Rock Lake. In response to increased eutrophication, especially in the James River Arm, the Missouri Clean Water Commission regulated reductions in point-source phosphorus loading to this reservoir. The STP (permitted release $\sim 160$ million L/day) began meeting the regulated discharge total phosphorus (TP) concentration of $0.5 \mathrm{mg} \mathrm{L}^{-1}$ in March 2001 as a consequence of a treatment plant upgrade. This paper describes the response of the James River Arm to this lake management effort.

Key words: Point-source loading, phosphorus, chlorophyll, reservoir

\section{Sampling sites and methods}

Discharge from the STP enters Wilsons Creek (Site I), which flows into the James River (Sites II and III) and subsequently into the James River Arm of Table Rock Lake, where samples were collected from four locations (Sites IV to VII; Fig. 1). Distance between the STP and the most down-lake site is $125 \mathrm{~km}$.

Lotic data were collected by the United States Geologic Survey (USGS) at Site I (station 07052152) in Wilsons Creek immediately downstream from STP during 1993-2003 and at Site III (station 07052500) during 1999-2003. Site II was monitored during 1998-2003 by the University of Missouri's Table Rock Lake Long-Term Monitoring Program (TRM). All three lotic sites were sampled year-round (Fig. 1). USGS data were compiled from the Water Resources page of the USGS web site (water.usgs.gov). Estimated monthly phosphorus releases from STP during July 1992 through September 2003 were supplied by City Utilities of Springfield.

Lake water quality data (Sites IV-VII) were generated through two University of Missouri projects: 
TRM and the Lakes of Missouri Volunteer Program (LMVP). Sampling methods for LMVP and the analytical methods used by both projects are detailed in OBRECHT et al. (1998). TRM data represent a composite of three distinct samples from the epilimnion (stratified conditions) or photic zone (mixed conditions), while LMVP data represent surface grab samples. Data from Sites IV and VI are from LMVP collections during 1995-2003 and 1992-2003, respectively (Fig. 1). Site VII data are from TRM during 1996-2003. Both projects contributed to 1995-2003 data from Site $V$, with TRM providing data from 1999-2001. Data from Sites IV, V and VI represent April-October collections. Site VII data were collected year-round, with stratified (April-October) and mixed (November-March) periods being evaluated separately.

Data were divided into pre- and post-upgrade periods using March 2001 as the cut-point and were compared (SPSS software) using the nonparametric Mann-Whitney $U$ test with significance set at $<0.05$, unless otherwise stated. Water quality trends are described using median values from the various sampling sites and periods.

\section{Results}

Between July 1992 and February 2001, the median monthly concentration of TP in STP discharge was $4010 \mu \mathrm{g} \mathrm{L}^{-1}$ (Table 1; Fig. 3). Median total monthly discharge during this period was $12,402 \mathrm{~kg}$ of TP and ranged from $1890-31,103 \mathrm{~kg}$ (Fig.2). Since the STP upgrade, the median monthly concentration of TP has decreased to $460 \mu \mathrm{g} \mathrm{L}^{-1}$ (Table 1; Fig.3), with the median total monthly discharge decreasing to $1217 \mathrm{~kg}$ of $\mathrm{TP}$ and ranging from $797-2459$ kg (Fig. 2). This $89 \%$ reduction in $\mathrm{P}$ load was directly reflected in Wilsons Creek (Site I), where TP levels declined $87 \%$ (median values $=3050 \mu \mathrm{g} \mathrm{L}^{-1}$ vs. $390 \mu \mathrm{g} \mathrm{L}^{-1}$; Table 1; Fig. 3). In the James River, median TP values were reduced $87 \%$ at Site II $\left(738 \mu \mathrm{g} \mathrm{L}^{-1}\right.$ vs. 95 $\left.\mu \mathrm{g} \mathrm{L}^{-1}\right)$ and $69 \%$ at Site III $\left(295 \mu \mathrm{g} \mathrm{L}^{-1}\right.$ vs. 90 $\mu \mathrm{g} \mathrm{L}^{-1}$; Table 1; Fig. 3). When expressed as TP concentration, this change amounts to a decrease of $2660 \mu \mathrm{g} \mathrm{L}^{-1}$ in Wilsons Creek, and respective declines of $643 \mu \mathrm{g} \mathrm{L}^{-1}$ and $205 \mu \mathrm{g} \mathrm{\textrm {L } ^ { - 1 }}$ at the two James River sites (Table 1; Fig. 3).

Table 1. Geometric mean (Geo-mean) values are presented along with minimum, median and maximum total phosphorus data $(\mu \mathrm{g} / \mathrm{L})$ from Springfield's Southwest treatment plant (STP) and seven sites in the James River Basin, pre and post-sewage treatment plant upgrade. STP data represent monthly values, with post-upgrade starting in March 2001. Sites IV-VI were sampled during stratified conditions.

\begin{tabular}{lccccccc}
\hline Site & $\begin{array}{c}\text { Sample } \\
\text { Period }\end{array}$ & Years & $\mathrm{n}$ & $\begin{array}{c}\text { Geo- } \\
\text { mean }\end{array}$ & Minimum & Median & Maximum \\
\hline STP & January- & $1992-2001$ & 104 & 4320 & 270 & 4010 & 21400 \\
& December & $2001-2003$ & 24 & 440 & 270 & 460 & 770 \\
I & January- & $1993-2000$ & 38 & 2730 & 430 & 3050 & 6000 \\
& December & $2001-2003$ & 15 & 400 & 250 & 390 & 760 \\
II & January- & $1998-2000$ & 19 & 519 & 119 & 738 & 1688 \\
& December & $2001-2003$ & 21 & 109 & 42 & 95 & 325 \\
III & January- & $1999-2000$ & 16 & 268 & 50 & 295 & 860 \\
& December & $2001-2003$ & 30 & 80 & 20 & 90 & 170 \\
IV & April- & $1995-2000$ & 46 & 129 & 70 & 126 & 347 \\
& October & $2001-2003$ & 24 & 80 & 59 & 77 & 122 \\
V & April- & $1995-2000$ & 31 & 68 & 11 & 70 & 201 \\
& October & $2001-2003$ & 16 & 42 & 23 & 40 & 78 \\
VI & April- & $1992-2000$ & 45 & 39 & 18 & 34 & 125 \\
& October & $2001-2003$ & 19 & 17 & 7 & 17 & 108 \\
VI1 & April- & $1996-2000$ & 41 & 16 & 4 & 15 & 62 \\
(stratified) & October & $2001-2003$ & 18 & 10 & 6 & 10 & 46 \\
VII & November- & $1996-2000$ & 26 & 25 & 11 & 24 & 111 \\
(mixis) & March & $2001-2003$ & 7 & 12 & 9 & 13 & 17 \\
\hline
\end{tabular}




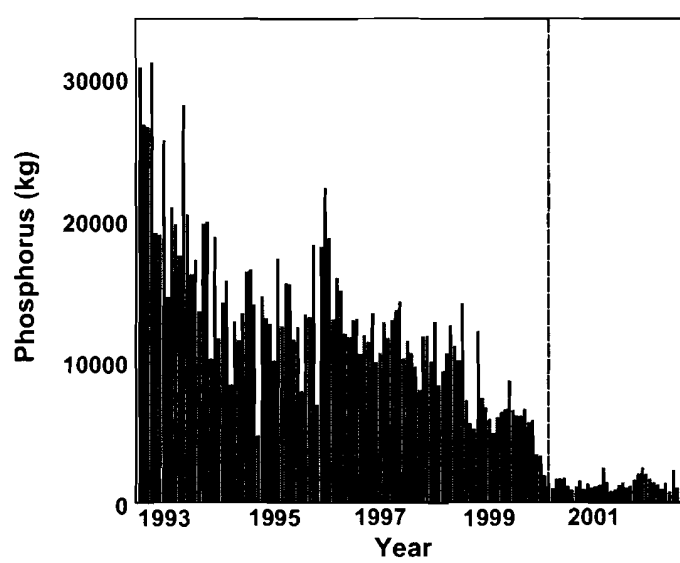

Fig. 2. Monthly phosphorus releases from the Springfield Southwest Treatment Plant for the period July 1992-September 2003. Dashed line represents completion of treatment plant upgrade, March 2001.

Summer TP levels declined in the James River Arm by some $40 \%$ in response to the STP upgrade (Table 1; Fig. 3 ), with median values declining between $33-50 \%$ at the various sites. On average, summer in-lake TP levels in the James River Arm declined by $25 \mu \mathrm{g} \mathrm{L}^{-1}$, with the decrease showing a strong longitudinal gradient ranging from $49 \mu \mathrm{g} \mathrm{L}^{-1}$ at the uplake location (Site IV) to $5 \mu \mathrm{g} \mathrm{L}^{-1}$ in the lower arm (Site VII; Fig. 3). During the unstratified period (November-March) there was a $46 \%$ decline in TP levels at Site VII (equating to $11 \mu \mathrm{g} \mathrm{L}^{-1}$; Table 1). Summer decreases in TP, resulting from the STP upgrade, were statistically significant at all seven sampling sites, as was the decrease at Site VII during mixis $(p=<0.01)$.

Post-upgrade changes in other limnological parameters in the James River Arm have been consistent with responses to P-load reduction. As expected, total nitrogen (TN) levels at all sites were virtually unchanged by the upgrade, resulting in a significant increase in TN:TP ratios throughout the system. Pre- and post-upgrade TN:TP ratios increased from 5-39 in the James River at Site II (the only lotic site where TN was measured). Upper James River Arm sites (IV and V) showed small, yet statistically significant increases in TN:TP ratios, increasing from 9-11 and 12-15, respectively (Fig. 4).
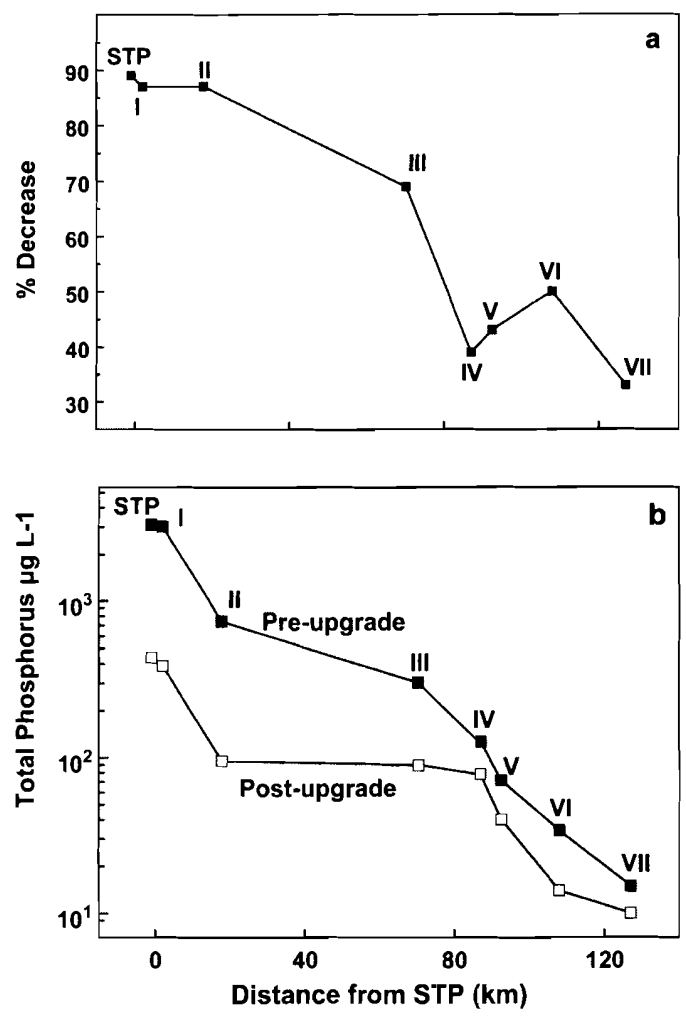

Fig. 3. Changes in phosphorus for Springfield Southwest Treatment Plant (STP) and seven sites in the James River Basin shown as (a) percent decrease in median values after treatment plant upgrade and (b) pre- and post upgrade median phosphorus concentrations. Site I is in Wilsons Creek (a tributary to the James River), Sites II and III are located in the James River, and Sites IV-VII are in the James River Arm of Table Rock Lake. Data from Sites IV-VII represent April-October sampling, while all other sites were monitored yearround.

Sites in the lower James River Arm (VI and VII) showed greater change, with TN:TP ratios increasing from $\sim 20$ to $>30$ (Fig. 4). Increased TN:TP marks a shift to greater P-limitation, particularly in the lower James River Arm.

Pre-upgrade, the median summertime yield of chlorophyll per unit TP (Chl:TP) was 0.5 across all sites in the James River Arm, which closely matches the average in non-turbid Missouri reservoirs (JONES \& KNOWLTON 1993). Post-upgrade, the median $\mathrm{Chl}$ :TP ratio in- 

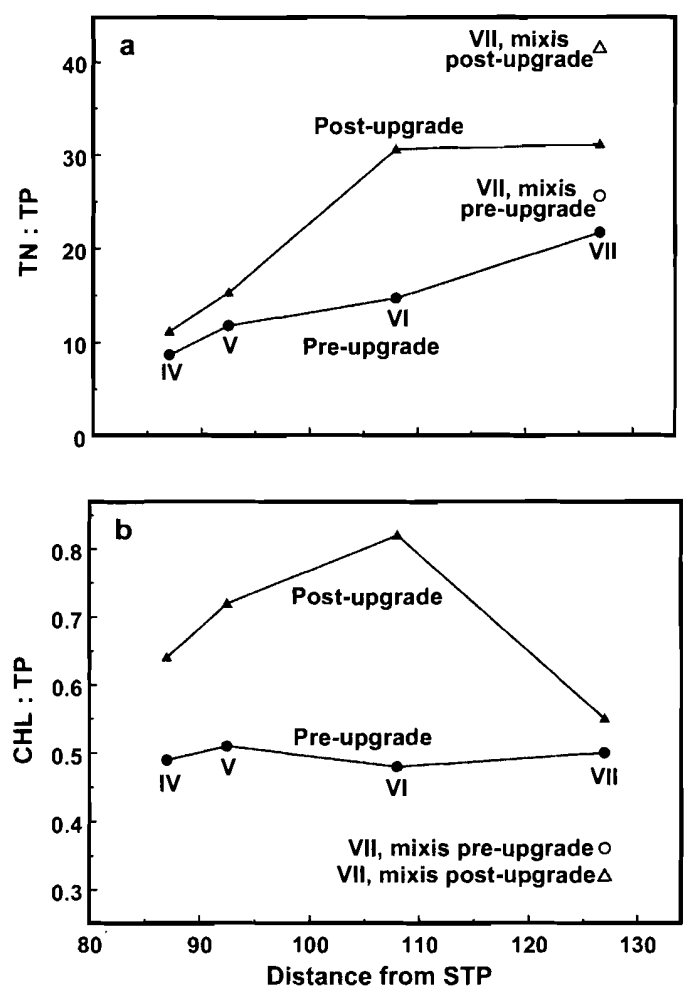

Fig. 4. Comparison of (a) Total Nitrogen (TN) to Total Phosphorus (TP) ratios and (b) Chlorophyll (Chl) to TP ratios for the four lake sites. Symbols with line represent the median values for pre- and post-treatment plant upgrade during stratified periods. Individual symbols represent median values for Site VII during mixis.

creased to 0.7 (Fig. 4). Ratios of Chl:TP increased significantly at the three upper James River Arm sites (IV, V, and VI, $p=<0.01$ ) while at Site VII the increase was minor. During stratification the increase in Chl:TP in the James River Arm was generally a result of lower TP concentrations as opposed to substantial shifts in Chl (Fig.5). Median summer Chl was unchanged at Site $\mathrm{V}\left(\sim 30 \mu \mathrm{g} \mathrm{L}^{-1}\right.$; Fig. 5) and showed non-significant declines of $14 \%$ at Site IV $\left(52.2 \mu \mathrm{g} \mathrm{L}^{-1}\right.$ vs. $\left.44.9 \mu \mathrm{g} \mathrm{L}^{-1}\right)$ and $6 \%$ at Site VII (7.2 $\mu \mathrm{g} \mathrm{L}^{-1}$ vs. $\left.6.8 \mu \mathrm{g} \mathrm{L}^{-1}\right)$. A $17 \%$ decline in summer $\mathrm{Chl}$ at Site VI was significant (median values of $16.8 \mu \mathrm{g} \mathrm{L}^{-1}$ vs. $14.0 \mu \mathrm{g} \mathrm{L}^{-1}, p=$ 0.054 ), as was the decline of $58 \%$ at Site VII
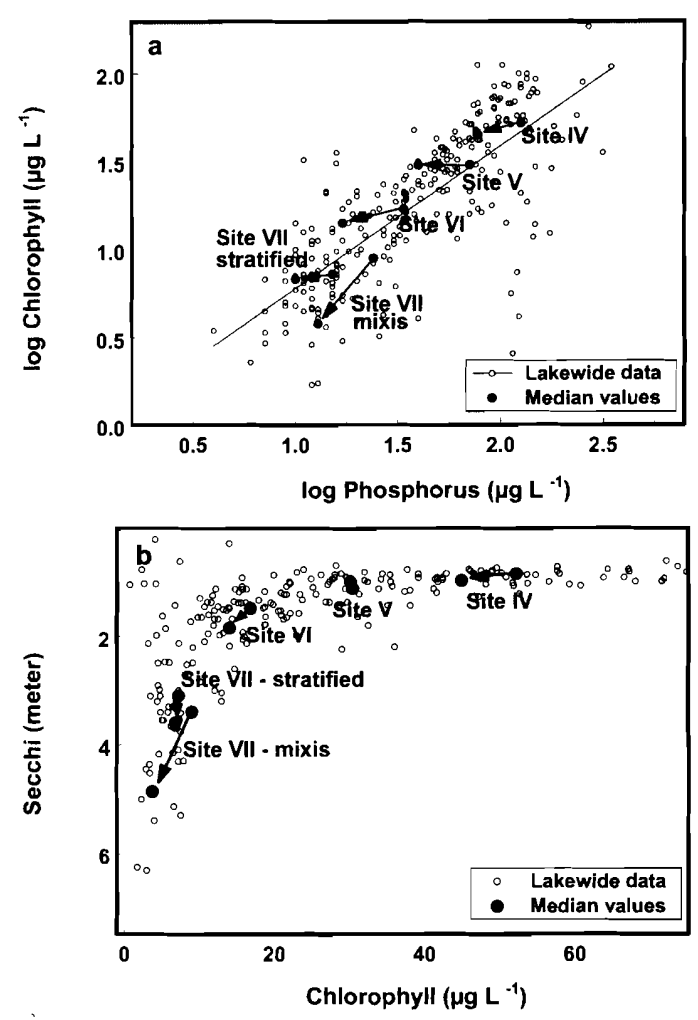

Fig. 5. Changes in the (a) phosphorus-chlorophyll and (b) chlorophyll-Secchi relations for the four lake sites. Open symbols represent individual values from 18 Table Rock Lake sites while solid symbols represent median values from pre- and post-treatment plant upgrade for the four sites in the James River Arm. Arrows indicate the change in the relations after upgrade.

during mixis (median values of $9.0 \mu \mathrm{g} \mathrm{L}^{-1}$ vs. $3.8 \mu \mathrm{g} \mathrm{L}^{-1}, p=<0.01$; Fig. 5).

Modest post-upgrade increases in median summertime Secchi transparency at Sites IV $(0.13 \mathrm{~m})$ and VI $(0.38 \mathrm{~m})$ were significant, as was an increase of $1.46 \mathrm{~m}$ at Site VII during mixis (Fig. 5). Non-significant increases in median Secchi transparency of $0.13 \mathrm{~m}$ and $0.53 \mathrm{~m}$ were measured at Sites V and VII (stratified), respectively (Fig. 5). Increases in Secchi transparency are consistent with reductions in $\mathrm{Chl}$ within the James River Arm and follow the general hyperbolic pattern between $\mathrm{Chl}$ and Secchi depth in lakes (Fig. 5). 


\section{Discussion}

Prior to this upgrade, the STP accounted for an estimated $64 \%$ of the P-load to the upper James River and $27 \%$ of the P-load to Table Rock Lake (Missouri Department of Natural Resources 2001 ). The $89 \%$ decrease in monthly $\mathrm{P}$ load from the STP matches the level of P reduction that has underpinned highly successful nutrient management practices in lakes worldwide (Edmondson 1972, SAS 1989). Reductions of this magnitude are often immediately measurable in receiving waters, as was demonstrated in the James River Arm (Fig. 3). Phosphorus reductions were sufficient at Sites IV and VI to shift trophic state classifications from hyper- to eutrophic and eu- to mesotrophic, respectively. The strong longitudinal gradient in TP concentrations along the James River Arm is characteristic of many large reservoirs in Missouri (JONES \& NOVAK 1981, KNOWLTON \& JONES 1989, KNOWLTON \& JONES 1995).

The large response to $\mathrm{P}$-load reduction at Site VII during mixis relative to the stratified summer period (Table 1) likely reflects the role of inflow patterns on in-lake P. During stratification, inflows often plunge below the epilimnion, thereby abridging their direct influence on surface waters while directly influencing the TP content of the lower, stratified water column (COOKE et al. 1993, KNOWLTON \& JONES 1995). Following the upgrade, plunging inflows would have delivered less TP to the hypolimnion during summer, thereby returning less TP to surface waters with destratification. During mixis, riverine inflows are typically dispersed throughout the water column and move downlake with hydrologic flow, directly influencing surface water chemistry. These processes likely account for the greater post-upgrade reduction in TP during mixis relative to the stratified period at Site VII.

The lack of a strong statistical response in Chl levels at most lake sites may partly be attributed to the variability of Chl:TP ratios in Missouri reservoirs (JONES et al. 1998) and most temperate lakes. Also, Chl:TP generally increases directly with TN:TP ratios (SMITH 1982). Reduction in TP in the James River Arm increased both ratios and helps explain the weak Chl response.
Increases in Secchi in the James River Arm match the scale of change expected based on predictions from a Chl-Secchi model for temperate lakes (JONES \& BACHMANN 1978). The Chl-Secchi relation has long been recognized as hyperbolic (EDMONDSON 1972, COOKE et al. 1993; Fig. 5), such that increases in water clarity are accelerated where $\mathrm{Chl}$ is $<10 \mu \mathrm{g} \mathrm{L}^{-1}$ (Site VII mixis; Fig. 5) relative to sites with $\mathrm{Chl}$ $>10 \mu \mathrm{g} \mathrm{L}^{-1}$, where reductions in Chl have minor influence on transparency (Site IV; Fig. 5). As such, based on water clarity, the benefits of the STP upgrade will be more obvious in the lower reaches of the James River Arm than at up-lake sites, even though changes in TP content are much smaller (Table 1).

Overall, this study supports the theory and practice of large-scale reductions in P-load to reverse eutrophication in temperate lakes. Additional data will be collected to further document in-lake benefits of this management application, both during summer and mixis. As we continue to monitor post-upgrade conditions we will improve the power of our data set for statistical comparisons. Future assessments will also evaluate the benefit of this upgrade on the lake below the James River Arm (Fig. 1).

\section{Acknowledgments}

Funding was provided by the Missouri Department of Natural Resources and the University of Missouri. We thank Bruce Perkins and many others for field collections and laboratory work. We also appreciate comments about the text by MATTHEW KNOWLTON, Eugene Welch and Patricia Chambers.

\section{References}

Cooke, G.D., Welch, E.G., Peterson, S.A. \& NEWROTH, P.R., 1993: Restoration and management of lakes and reservoirs. - Lewis Publishing. Boca Raton, 548:pp.

EDMONDSON, W.T., 1972: Nutrients and phytoplankton in Lake Washington. - In: LIKENS, G.E. (Ed.): Symposium on nutrients and eutrophication, the limiting nutrient controversy: 172-188. American Soc. of Limnol. and Oceanogr.. Spec. Symp. No. 1. Allen Press, Lawrence, Kansas.

JONES, J.R. \& BACHMANN, R.W., 1978: Trophic status of Iówa lakes in relation to origin and glacial geology. Hydrobiologia 57: 267-273.

JONES, J.R. \& NOVAK, J.T., 1981: Limnological characteristics of Lake of the Ozarks, Missouri. - Verh. Internat. Verein. Limnol. 21: 919-925. 
JONES, J.R. \& KNOWLTON, M.F., 1993: Limnology of Missouri reservoirs: An analysis of regional patterns. - Lake Reserv. Managem. 8: 17-30.

JONES, I.R., KNOWLTON, M.F. \& KAISER, M.S., 1998: Effects of aggregation on chlorophyll-phosphorus relations in Missouri reservoirs. - Lake Reserv. Managem. 14: 1-9.

Jones, J.R., Knowlton, M.F., Obrecht, D.V. \& CoOK, E.A., 2004: Importance of landscape variables and morphology on nutrients in Missouri reservoirs. Can. J. Fish. Aquat. Sci. 61: 1503-1512.

KNOWLTON, M.F. \& JONES, J.R., 1989: Summer distribution of nutrients, phytoplankton and dissolved oxygen in relation to hydrology in Table Rock Lake, a large midwestern reservoir. - Archiv. Hydrobiol. Suppl. 83: 197-225.

KNOWLTON, M.F. \& JONES, J.R., 1990: Occurrence and prediction of algal blooms in Lake Taneycomo. Lake Reserv. Manage. 6: 143-152.

KNOWLTON, M.F. \& JONES, J.R., 1995: Temporal and spatial dynamics of suspended sediment, nutrients and algal biomass in Mark Twain Lake, Missouri. Archiv. Hydrobiol. 135: 145-178.
Missouri Department of Natural Resources, 2001: Total maximum daily load (TMDL) for James River, Webster, Greene, Christian and Stone Counties, Missouri, Jefferson City, Missouri, $31 \mathrm{pp}$.

Obrecht, D. V., Milanick, M., Perkins, B.D., Ready, D. \& JONES, J.R., 1998: Evaluation of data generated from lake samples collected by volunteers. - Lake Reserv. Managem. 14: 21-27.

SAS, H., 1989: Lake restoration by reduction of nutrient loading: expectations, experiences, extrapolations. Academia Verlag., Richarz 497 pp.

SмITH, V., 1982: The nitrogen and phosphorus dependence of algal biomass in lakes: An empirical and theoretical analysis. - Limnol. Oceanogr. 27: 1101-1112.

\section{Authors' address:}

Daniel Obrecht, Anthony P. Thorpe, and John R. JONES, Department of Fisheries and Wildlife Sciences, 302 ABNR Building, University of Missouri, Columbia, Missouri 65211, USA. E-mail: jonesj@missouri.edu 